\title{
A new genus and species of the family Pennellidae (Copepoda, Siphonostomatoida) infecting the Pacific viperfish Chauliodus macouni
}

Susumu Ohtsuka ${ }^{1, *}$, Dhugal J. Lindsay ${ }^{2}$, and Kunihiko Izawa ${ }^{3}$

${ }^{1}$ Takehara Station, Setouchi Field Science Center, Graduate School of Biosphere Science, Hiroshima University, 5-8-1 Minato-machi, Takehara, Hiroshima 725-0024, Japan

2 Research and Development Center for Submarine Resources, Environmental Impact Assessment Research Group, Japan Agency for Marine-Earth Science and Technology, 2-15 Natsushima-cho. Yokosuka, Kanagawa 237-0061, Japan

${ }^{3}$ Izawa Marine Biological Laboratory, 795-16 Kannonji, Tsu, Mie 514-0062, Japan

Received 9 November 2017, Accepted 17 January 2018, Published online 9 February 2018

\begin{abstract}
A new genus and species of pennellid copepod, Protosarcotretes nishikawain. g., n. sp., is described on the basis of an ovigerous female infecting a Pacific viperfish Chauliodus macouni collected from the deepwaters of Suruga Bay, Japan. The new genus exhibits the most plesiomorphic states in the first to fourth legs of pennellids, and is differentiated from two closely related pennellid genera Sarcotretes and Lernaeenicus by the morphology of the oral appendages. Two species of the genus Lernaeenicus are transferred to the new genus as Protosarcotretes multilobatus (Lewis, 1959) n. comb. and Protosarcotretes gnavus (Leigh-Sharpe, 1934) n. comb. The host specificity and life cycle of deep-sea pennellids are discussed. Sarcotretes scopeli Jungersen, 1911 and Cardiodectes bellottii (Richiardi, 1882) show low differentiated host-specificity, while P. nishikawai seems to be limited to the Stomiidae, which are rare hosts of pennellids, in contrast to the Myctophidae family. In the Pennellidae family, two patterns of the life cycle are found: with or without naupliar stages.
\end{abstract}

Keywords: Copepoda; deep-sea; Pennellidae; taxonomy

Résumé - Un nouveau genre et une nouvelle espèce de la famille Pennellidae (Copepoda, Siphonostomatoida) infectant le poisson-vipère du Pacifique Chauliodus macouni. Un nouveau genre et espèce de copépode Pennellidae, Protosarcotretes nishikawai n. g., n. sp., est décrit sur la base d'une femelle ovigère infectant le poisson-vipère du Pacifique Chauliodus macouni prélevé dans les eaux profondes de la baie de Suruga, au Japon. Le nouveau genre présente les états les plus plésiomorphes des appendices 1 à 4 des Pennellidae et se différencie de deux genres apparentés, Sarcotretes et Lernaeenicus, par la morphologie des appendices oraux. Deux espèces du genre Lernaeenicus sont transférées dans le nouveau genre comme Protosarcotretes multilobatus (Lewis, 1959) n. comb. et Protosarcotretes gnavus (Leigh-Sharpe, 1934) n. comb. La spécificité de l'hôte et le cycle de vie des Pennellidae profonds sont discutés. Sarcotretes scopeli Jungersen, 1911 et Cardiodectes bellottii (Richiardi, 1882) montrent une spécificité d'hôte peu différenciée, tandis que P. nishikawai semble être limité aux Stomiidae, rarement utilisés comme hôtes par les pennellidés, contrairement à la famille Myctophidae. Dans la famille Pennellidae, on retrouve deux types de cycle de vie, avec ou sans étapes nauplius.

\section{Introduction}

Pennellid copepods are highly modified, meso- or ectoparasitic copepods infecting marine fish and mammals as

\footnotetext{
*Corresponding author: ohtsuka@hiroshima-u.ac.jp
}

definitive hosts [8]. The life cycle of the family is complex, with some genera needing two hosts, while others require only a single host $[7,8,20,24]$. The intermediate hosts of Cardiodectes Wilson, 1917 and Pennella Oken, 1815, with two hosts each, are free-swimming molluscs $[8,16,31,36]$. Some species of the genera Pennella, Peniculus 
Nordmann, 1832 and Lernaeenicus Le Sueur, 1824 heavily parasitize wild and cultured commercially important fish and squids throughout the world's oceans, presumably causing economic losses [3,20,28,31,32,33,34,35,38,48]. The genera Cardiodectes and Sarcotretes Jungersen, 1911 have been found on mesopelagic and bathypelagic fish $[5,8,13,17,18,22,46,49]$.

During a survey on the deep-water plankton of Suruga Bay, Japan, an undescribed pennellid copepod was discovered on the Pacific viperfish Chauliodus macouni, 1890, Bean (Fig. 1A, B). This animal generally resembles three pennellid genera, Sarcotretes, Lernaeenicus and Peniculus, placing it within the family Pennellidae as defined by Boxshall [4], although the first two genera appear taxonomically confused. In Sarcotretes and Lernaeenicus, the neck (see "ne" in Fig. 1) is composed of the first to fourth pedigerous somites, while in Peniculus, the fourth pedigerous somite is incorporated into the trunk [8]. According to the keys to pennellid genera provided by Kabata [23] and Boxshall \& Halsey [8], a feature distinguishing these two genera is the presence (in Sarcotretes) or absence (in Lernaeenicus) of a middle constriction of the neck. However, this is not applicable to all species of the former. For example, Sarcotretes longirostris Ho, Nagasawa, \& Kim, 2007 bears a slender neck without a constriction midway (see Fig. 1A in Ho et al. [17]). On the other hand, Lernaeenicus also seems to be a catch-all group when the morphological variability in the cephalosomes, abdomens and legs is considered. Some species of Lernaeenicus bear a well-developed abdomen, while in others it is highly reduced like in Sarcotretes. In many species, legs 3 and 4 are uniramous, while in $L$. multilobatus Lewis, 1959 they are biramous. Castro Romero [11] provided a different key to pennellid genera, and suggested that the key characteristics differentiating these two genera are the morphology of the cephalic holdfasts, proboscis and labium.

The present paper deals with the taxonomy of the undescribed pennellid copepod parasitizing the Pacific viperfish, and discusses the validity of the genera Sarcotretes and Lernaeenicus.

\section{Materials and methods}

The present specimens (a parasitic copepod attached posterior to the right eye of its host fish) were captured in Suruga Bay $\left(35^{\circ} 02.3^{\prime} \mathrm{N}, 138^{\circ} 40.5^{\prime} \mathrm{E}\right)$ between 12:21-13:51 on September 8, 2017 in an oblique tow (0-810 m depth) of an ORI net (335 $\mu \mathrm{m}$ mesh, $1.6 \mathrm{~m}$ mouth diameter) during cruise SRM17-9-VPR of the T/V Hokuto (Tokai University). The specimens were photographed live before being preserved in $99.5 \%$ ethanol (see Fig. 1). The host fish was identified as Chauliodus macouni Bean, 1890 by reference to Nakabo [29].

The parasitic copepod was removed from the host tissue and then partly dissected in lactophenol with a pair of fine needles under a dissecting microscope (SZX7, Olympus Co., Ltd.). The body and appendages were examined in lactophenol and drawn with the aid of a camera lucida attached to a compound microscope (BX53,
Olympus Co., Ltd.). The specimens were deposited in the Kitakyushu Museum of Natural History and Human History (KMNH). Terminology follows Huys \& Boxshall [19] and Ho et al. [17].

\section{Results}

\section{Genus Protosarcotretes n. g.}

urn:lsid:zoobank.org:act:C3402CB8-65B1-40A1-9A9AEA03548D5E64

Order Siphonostomatoida Burmeister, 1835

Family Pennellidae Burmeister, 1835

Type species. Protosarcotretes nishikawai n. g., n. sp. (by monotypy).

Other species. Protosarcotretes multilobatus (Lewis, 1959) (new combination); Protosarcotretes gnavus (Leigh-Sharpe, 1934) (new combination).

Etymology. The new generic name is derived from proto (Greek prefixed, meaning primitive) and a closely related genus Sarcotretes, and refers to the primitive condition, especially in the segmentation and setation of legs 1-4, of the new genus. Gender masculine.

Diagnosis. Body straight, without brush-like structure on abdomen. Cephalothoracic holdfast represented by pair of lateral expansions. Oral cone weakly produced anteroventrally to form proboscis. Neck comprising pedigers 2-4, first urosomite and anterior part of trunk. Trunk cylindrical; abdomen highly reduced; caudal rami present, bilobate with 2 and 4 setae, respectively. Egg string uniseriate. Total length ca. $10 \mathrm{~mm}$.

Antennule indistinctly 4-segmented. Antenna 3-segmented, heavily sclerotized; second segment produced at subterminal corner into stout triangular process; third segment curved inward to form subchela with process of preceding segment, bearing minute basal seta. Mandible simple stylet-like, with no teeth distally. Maxillule unilobate, inner lobe with 2 terminal setae; outer lobe absent. Maxilla 2-segmented; first segment with no accessory process; second segment bearing 4 rows of spinular prominences on calamus.

Legs 1-4 biramous; rami 2-segmented; armature elements shown in Table 1.

Remarks. Once both Sarcotretes and Lernaeenicus are rigidly defined, it is evident that the establishment of a new genus for the present material is warranted. However, since many taxa belonging to these genera were poorly described in the 18th and at the beginning of the 19th centuries, the definitions below are still tentative and await a complete revision (see Raja et al. [38]).

Adult females of Sarcotretes are relatively rigidly defined by the following synapomorphies in comparison with other closely related pennellid genera: (1) paired cephalic holdfasts expanded laterally, (2) oral cone moderately or highly developed, produced anteroventrally to form proboscis, (3) abdomen highly reduced, (4) caudal rami absent, (5) leg 3 uniramous, and leg 4 represented by vestige, (6) armature elements of legs 1-3 as presented in Table 1 (based on Uyeno et al. [46]), and (7) rudimentary 

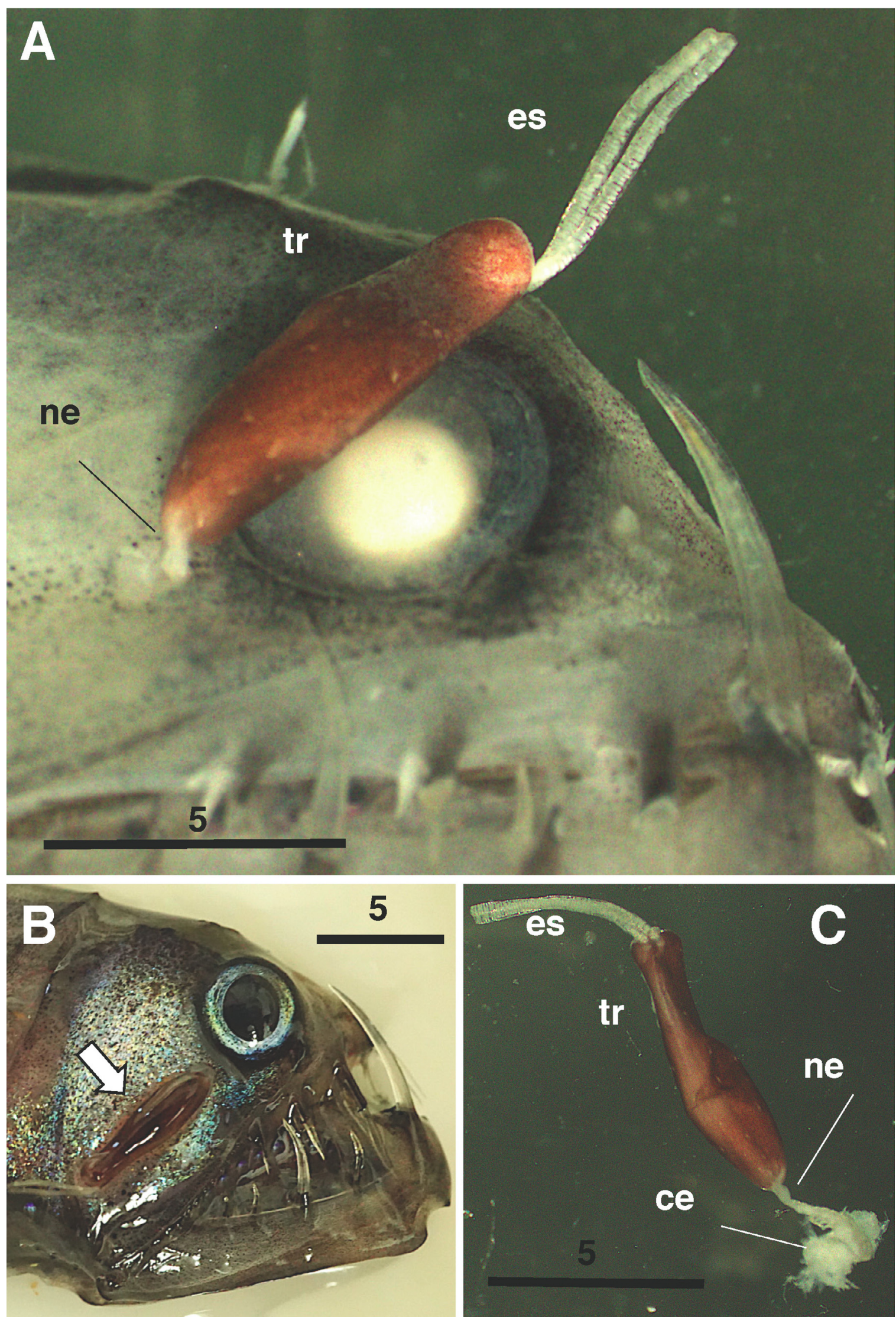

Figure 1. Protosarcotretes nishikawain. g., n. sp., adult female (holotype). A. whole specimen, in-situ on host, after fixation; B. whole specimen (arrowed), in-situ on host, before fixation; C. whole specimen, dissected out of host. Abbreviations: ce: cephalothorax, es: egg string, ne: neck, tr: trunk. Scales in mm. 
Table 1. Segmentation and setation of legs 1 to 4 of Sarcotretes, Lernaeenicus and Protosarcotretes n. g. Bold letters indicate differences among genera. Number in parentheses shows variation.

\begin{tabular}{|c|c|c|c|c|}
\hline Genus & Leg & Protopod & Exopod & Endopod \\
\hline \multirow[t]{4}{*}{ Sarcotretes } & 1 & $1-0$ & $\mathrm{I}-1, \mathrm{I}, \mathrm{I}, 5$ & $0-1,7$ \\
\hline & 2 & $1-0$ & $\mathrm{I}-1, \mathbf{I}, \mathbf{I}, \mathbf{5}$ & $0-1,7$ \\
\hline & 3 & $1-0$ & $0-0, I, I, 4$ & absent \\
\hline & 4 & absent & absent & absent \\
\hline \multirow[t]{4}{*}{ Lernaeenicus } & 1 & $1-1$ & $\mathrm{I}-1, \mathrm{I}, \mathrm{I}, 5$ & $0-1,7$ \\
\hline & 2 & $1-0$ & $0(\mathrm{I})-1, \mathrm{I}, 6$ & $0-1,7$ \\
\hline & 3 & $1-0$ & $0-0, I, 5$ & absent \\
\hline & 4 & $1-0$ & $0-0, \mathrm{I}, 4$ & absent \\
\hline \multirow[t]{4}{*}{ Protosarcotretes n. g. } & 1 & $1-1$ & $\mathrm{I}-1, \mathrm{I}, \mathrm{I}, 5$ & $0-1,8$ \\
\hline & 2 & $1-0$ & I-1, II,I,5 & $0-1,7$ \\
\hline & 3 & $1-0$ & $\mathrm{I}-1, \mathbf{I}, \mathbf{I}, \mathbf{5}$ & $0-1,4$ \\
\hline & 4 & $1-0$ & I-1, I,I,5 & $0-1,3$ \\
\hline
\end{tabular}

outer spines present on first exopodal segments of legs 1 and 2. Based on observations of the labium by Castro Romero \& Kuroki [12] and Castro Romero [11], those of Sarcotretes bear a pair of pad-like structures. The body length of adult females ranged from $13-85 \mathrm{~mm}$ $[13,17,18,22,46,49]$. This genus has so far accommodated the following four valid species: S. eristaliformis (Brian, 1908); S. scopeli Jungersen, 1911; S. longrostris Ho, Nagasawa, \& Kim, 2007 and S. umitake Uyeno, Wakabayashi \& Nagasawa, 2014. Sarcotretes mainly parasitizes deep-sea planktonic and benthic fish.

Adult females of Lernaeenicus are characterized by: (1) cephalothorax usually bearing 3 or more dorsal, simple or branching processes/knobs (at least one median and 2 lateral), which are sometimes heavily sclerotized, (2) oral cone moderately or highly produced anteroventrally, (3) abdomen elongate, (4) caudal rami present or absent, (5) first segment of maxilla with one or more processes, (6) legs 3 and 4 both retained, uniramous, (7) armature elements shown in Table 1 (based on Shiino [42,43], Kabata [23], Sebastian \& George [41], Schram [39], Oldewage [30], and Knoff \& Boeger [25]), and (8) rudimentary outer spine present on first exopodal segment of leg 1 . In addition, Castro Romero [11] considered that the presence of a row of spinules or scale-like plates on the labium is important to define the genus. The body length is highly variable, ranging from 12 to $126 \mathrm{~mm},[23,30,38,40,49]$. According to Boxshall \& Walter [9], 32 valid species are assigned to Lernaeenicus. However, it seems that Lernaeenicus quadrilobatus Yamaguti \& Utiumi, 1953 infecting the blue lantern-fish Diaphus coeruleus (Klunzinger) is intermediate between Lernaeenicus and Sarcotretes on the basis of the morphology of the cephalothorax, abdomen and legs. Lernaeenicus gracilis (Heller, 1865), infecting the shallow-water carangid Lichina amia (Linnaeus), is also enigmatic, being similar to the new genus in having the cephalothorax with a pair of simple lateral expansions and a short abdomen. However, Heller [15] mentioned that the four pairs of legs below the neck are completely the same as in L. monillaris (=Lernaeenicus sprattae) with legs 3 and 4 uniramous. A taxonomic conclusion is pending until this species is redescribed in detail.

Raja et al. [38] summarized the host-parasite relationships of 13 species of Lernaeenicus occurring in the Indian Ocean: their hosts are restricted to shallow water families such as Blenniidae, Carangidae, Engraulidae, Hemiramphidae, Mugilidae, Nemipteridae, Polynemidae, and Scombridae.

The new genus described here shows many plesiomorphies in the oral cone and legs (see Boxshall [4]), but some states in the mandible, maxillule and maxilla can be regarded as apomorphic. Although Lernaeenicus multilobatus Lewis, 1959 parasitic on the angler-fish Gigantactis sp. (Gigantacinidae), was poorly described by Lewis [27], it can be assigned to the new genus by: (1) the holdfast composed of a pair of cephalothoracic lateral expansions, (2) the abdomen being highly reduced, and (3) leg 4 being biramous. Lernaeenicus gnavus Leigh-Sharpe, 1934 was poorly described on the basis of a single adult female with a damaged cephalothorax, in which the oral cone cannot be seen in Fig. 35 of the original description [26]. However, the morphological and ecological features suggest that it is probably assignable to the new genus we describe: (1) the abdomen is reduced; (2) the body length is about $10 \mathrm{~mm}$, regardless of the damaged cephalothorax; (3) the host fish Polyipnus spinosus Günther belongs to the deep-sea family Sternoptychidae.

An evolutionary trend in reduction of segmentation of the legs is distinct in adult females of the ProtosarcotretesSarcotretes-Lernaeenicus lineage (present study). Similar patterns can be found in the legs of parasitic copepod families such as Chondracanthidae, Pandaridae, and Hatschekiidae [23]. Generally, anterior legs are relatively conserved and show full segmentation in their rami, while posterior legs tend to have the number of segments reduced, finally leading to a vestigial condition (Table 1).

\section{Protosarcotretes nishikawai n. g., n. sp.}

urn:lsid:zoobank.org:act:BA8F41A1-F58B-4922-81AA3EA509AD9124

(Figs 1, 2)

Type-material. Holotype, one ovigerous female infecting the Pacific viperfish Chauliodus macouni (standard length $127 \mathrm{~mm}$ ) (KMNH VR 110,001) collected from depths of $0-810 \mathrm{~m}$, Suruga Bay $\left(35^{\circ} 02.3^{\prime} \mathrm{N}, 138^{\circ} 40.5^{\prime} \mathrm{E}\right)$ between local time 12:21-13:51 on September 8, 2017, cephalothorax partly dissected and mounted on a glass slide, body in vial, KMNH IvR 500,945.

Type-locality. Suruga Bay $\left(35^{\circ} 02.3^{\prime} \mathrm{N}, 138^{\circ} 40.5^{\prime} \mathrm{E}\right)$, off Japan.

Host and attachment site. Chauliodus macouni Bean; attachment site: skin posterior to right eye.

Etymology. The new specific name is in honor of Professor Jun Nishikawa (Tokai University) who was helpful in collection of the present parasitic copepod during his research cruise in September 2017. 


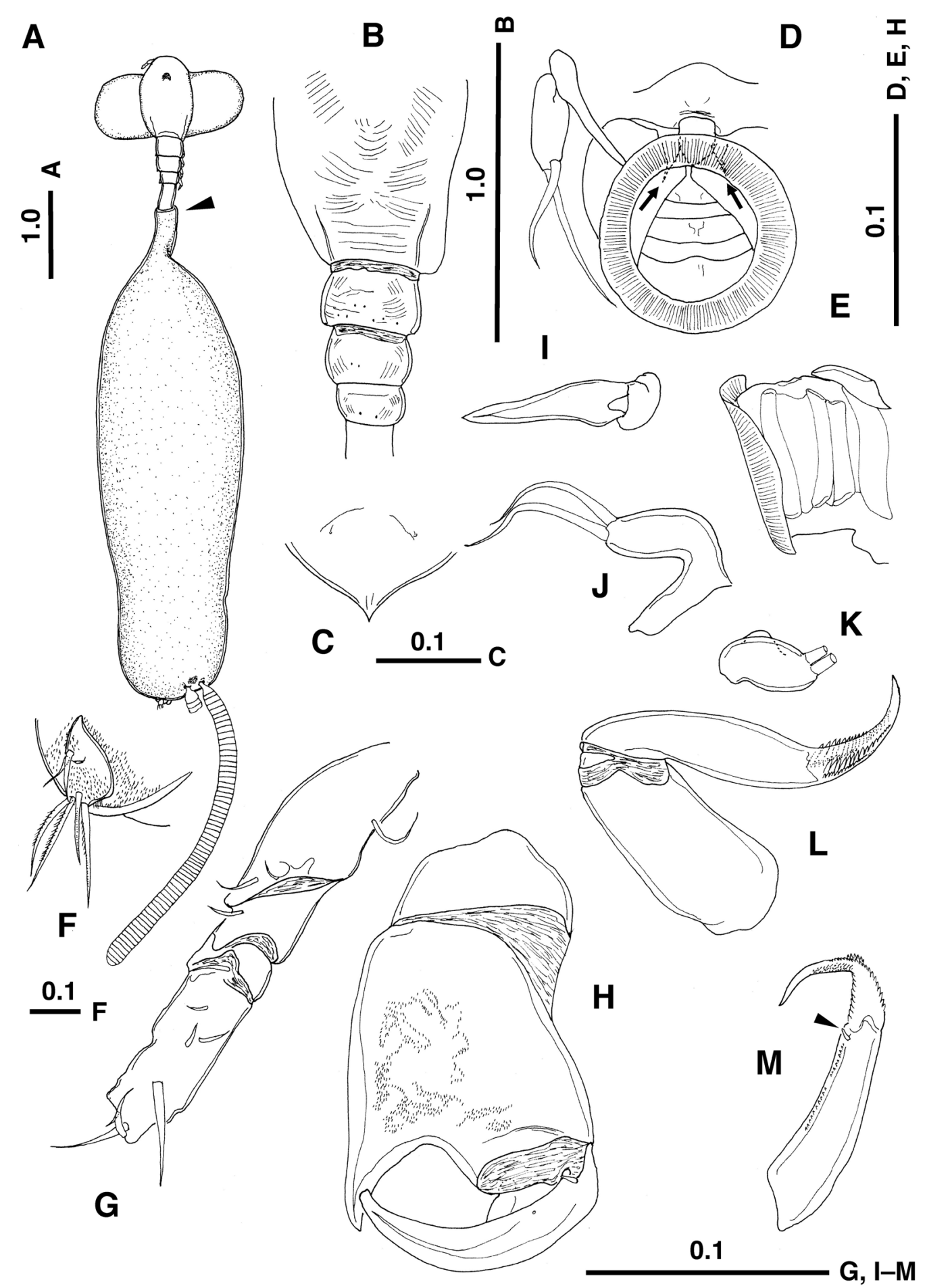

Figure 2. Protosarcotretes nishikawai n. g., n. sp., adult female (holotype). A. Habitus, dorsal view (trunk twisted), embedded part anterior to arrowhead; B. Pedigers 1-4, dorsal view; C. Rostrum; D. Oral cone, ventral view, pair of buccal stylets arrowed; E. Oral cone, lateral view; F. Caudal ramus; G. Antennule; H. Antenna; I. Mandible; J. Maxillule; K. Maxillule, setae omitted; L. Maxilla; M. Terminal segment of maxilla, canna arrowed. Scales in $\mathrm{mm}$.

Description. Adult ovigerous female. Body (Figs 1,2A) consisting of expanded cephalosome, relatively short neck and cylindrical trunk. Trunk tinged dark brown before fixation (Fig. 1B), and bearing white spots sparsely after fixation (Fig. 1A, C). Total length $10.6 \mathrm{~mm}$ from anterior tip of cephalosome to posterior end of caudal ramus, excluding setae. Parts anterior to genital complex (trunk) embedded in host tissue (arrow in Fig. 2A). Integument of dorsal side of posterior parts of cephalothorax and pedigers 2-4 finely wrinkled (Fig. 2B). Cephalothorax 


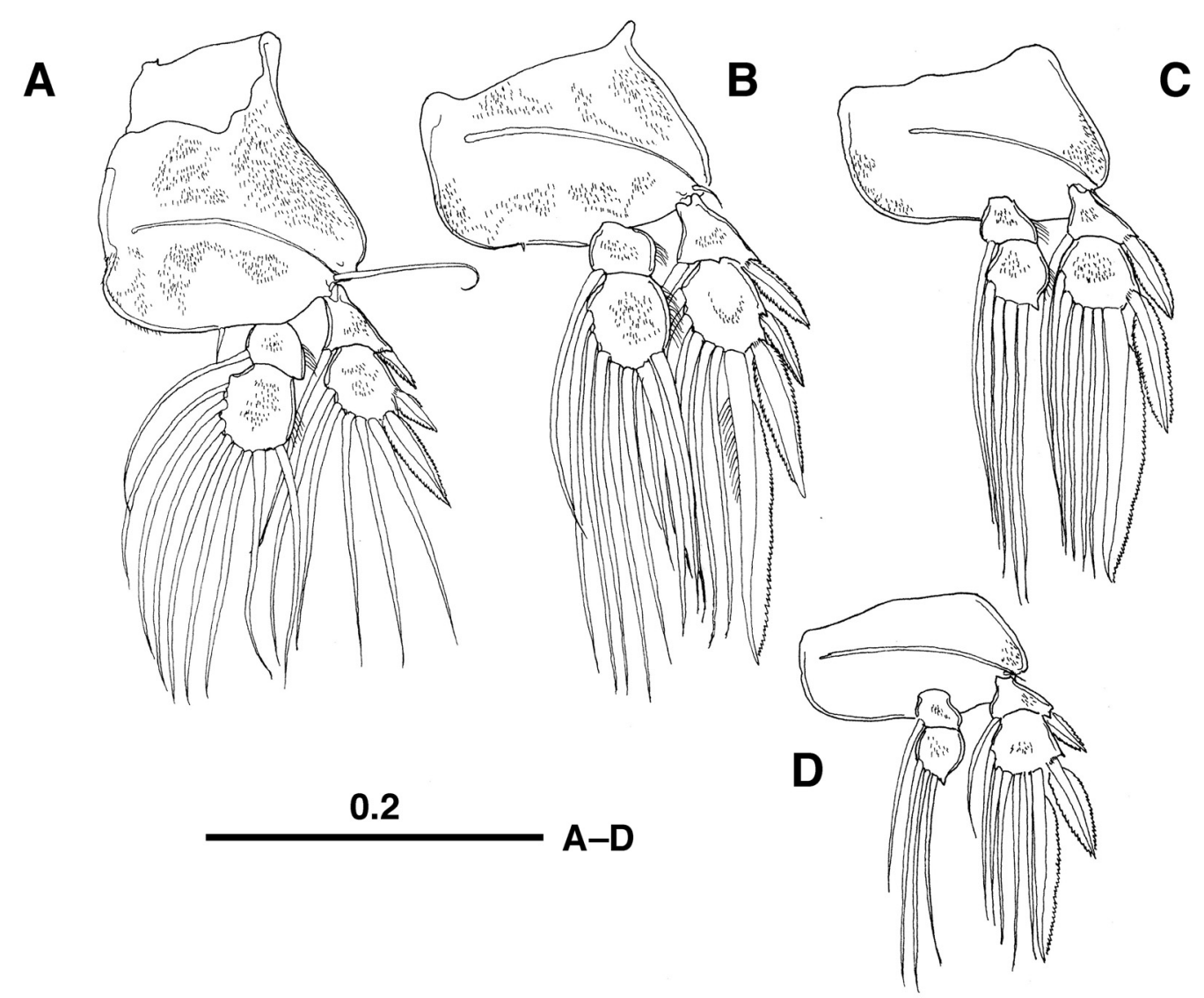

Figure 3. Protosarcotretes nishikawai n. g., n. sp., adult female (holotype). A. Leg 1, anterior surface; B. Leg 2, anterior surface; C. Leg 3, anterior surface, D. Leg 4, anterior surface. Scales in mm.

expanded laterally, forming paired holdfasts covered with thin cuticular membrane. Rostrum (Fig. 2C) pointed at tip, with pair of fine hair-like sensilla anteriorly. First pediger incompletely incorporated into cephalon. Naupliar eyes present (Fig. 2A). Oral cone (Fig. 2D, E) produced ventrally, not forming elongate proboscis, with four ring-like structures (Fig. 2D); pair of buccal stylets positioned anteriorly (arrowed in Fig. 2D). Neck comprising pedigers $2-4$, first urosomite and anterior part of trunk, $1.4 \mathrm{~mm}$ in length. Trunk (Figs 1C, 2A) $7.2 \mathrm{~mm}$ in length, about 2.2 times as long as cephalothorax and neck combined; paired gonopores located subterminally; abdomen highly reduced, furnished with minute prominences; caudal ramus (Fig. 2F) bilobate, outer and inner lobes bearing 2 and 4 setae, respectively. Egg string (Figs 1, 2A) straight, uniseriate, containing 65 eggs in left sac.

Antennule (Fig. 2G) incompletely 4-segmented, possibly many setal elements missing, probably during dissection. Antenna (Fig. 2H) heavily chitinized, 3segmented; second segment ornamented with minute prominences on surface, remarkably produced into triangular subterminal process on inner margin, opposing tip of subchela formed by third segment; third segment curved inward, with minute basal element on anterior surface. Mandible (Fig. 2I) simple stylet with no teeth terminally. Maxillule (Fig. 2J, K) unilobate, inner lobe with two terminal setae of unequal length; outer lobe absent. Maxilla (Fig. 2L, M) 2-segmented; first segment (lacertus) unarmed; second segment (brachium) reflexed, with terminal third (calamus) smoothly curved inward, tapering distally, having 2 rows of spinular prominences on each side; canna subterminally located on second segment, small (arrow in Fig. 2M).

Legs 1-4 (Figs 3A-D) biramous, with 2-segmented rami; armature elements shown in Table 1; protopods with suture between coxa and basis distinctly visible; protopod and rami sparsely ornamented with minute spinules on surface.

Remarks. The new species is easily distinguished from its poorly described congener, P. multilobatus (Lewis, 1959) by the morphology of the holdfast: simple in the former and ramified in the latter. It differs from P. gnavus (Leigh-Sharpe, 1934) by the relative length of the trunk to the cephalothorax and neck combined (2.2 times in $P$. nishikawai n. sp. vs ca. 0.7 in $P$. gnavus).

\section{Discussion}

Members of the parasitic family Pennellidae have successfully colonized the deep-sea $[5,8,49]$. Colonization of pennellids into the deep-sea seems to have occurred repeatedly, because the most basal genus Peniculus is a shallow-water taxon $[4,23,47]$ and more derived groups are 
Table 2. Host-parasite relationships of pennellid copepods infecting deep-sea fish. Scientific names of fish hosts are based on FishBase (2017) [14].

Parasitic copepod Jungersen, 1911

Sarcotretes eristaliformis (Brian, 1908)

Sarcotretes longirostris Ho et al., 2004

Sarcotretes umitake Uyeno et al., 2014

\section{Lernaeenicus} gonostonae Kensley \& Grindley, 1973

Lernaeenicus quadrilobatus Yamaguti \& Utiumi, 1959

\section{Protosarcotretes} nishikawai n. g., n. sp.

Protosarcotretes gnavus (Leigh-Sharpe, 1934)

Protosarcotretes multilobatus (Lewis, 1959)

Exopenna crimmeni (Boxshall, 1986)

Host family
Myctophidae

Host species

Benthosema glaciale (Reinhardt), Diogenichthys atlanticus

(Tåning), Electrona carlsbergi (Tåning), Gonichthys cocco

(Cocco), Gymnoscopelus nicholsi (Gilbert), Gymnoscopelus piabilis (Whitley), Protomyctophum choriodon Hulley,

Protomyctophum tenisoni (Norman), Krefftichthys anderssoni

(Lönnberg), Lampichthys procerus (Brauer), Metelectrona ventralis (Becker), Myctophum punctatum Rafinesque,

Notoscopelus resplendens (Richardson), Protomyctophum bolini

(Fraser-Brunner), Protomyctophum choriodon Hulley,

Protomyctophum tenisoni (Norman), Symbolophorus evermanni (Gilbert)

Melamphaidae

Sternoptychidae

Gempylidae

Gonostomatidae

Macrouridae

Melanocetidae

Stomiidae

Sternoptychidae

\section{Scopelobery}

(Parr), Scopeloberyx robustus (Günther)

Polyipnus asteroides Schultz, Sternoptyx diaphana Hermann

Gempylus serpens Cuvier

Cyclothone atraria Gilbert

Hymenogadus gracilis (Gilbert \& Hubbs)

Melanocetus johnsonii Günther

Photostomias tantillux Kenaley

Sternoptyx diaphana (Hermann), Sternoptyx obscura Garman, Sternoptyx pseudobscura Baird

Macrouridae

Eurypharyngidae

Gonostomatidae

Ipnopidae

Myctophidae

Stomiidae

Nomeidae

Hymenocephalus striatissimus Jordan \& Gilbert, Nezumia bairdii (Goode \& Bean)

Eurypharynx pelecanoides Vaillant

Sigmops gracilis (Günther)

Bathypterois dubius Vaillant

unidentified myctophids

Malacosteus niger Ayres

Psenes pellucidus Luüken

$[17]$

Macrouridae

Coelorinchus jordani Smith \& Pope

[46]

Gonostomatidae

Sigmops elongatus (Günther)

[9]

Myctophidae Diaphus caeruleus (Klunzinger)

$[50]$

Stomiidae

Chauliodus macouni Bean

Present study

Sternoptychidae

Polyipnus spinosus Günther

$[26]$

Gigantactinidae Gigantactis sp.

Moriidae

Antimora rostrata (Günther)

Reference

$[9,13,18,22,49]$

\section{9]}


Table2. (continued).

\begin{tabular}{lll}
\hline Parasitic copepod & Host family & Host species \\
\hline Cardiodectes & Myctophidae & Benthosema glaciale, Ceratoscopelus townsendi (Eigenmann \& \\
bellottii (Richiardi, & Eigenmann), Ceratoscopelus warmingii (Lütken), Diaphus theta \\
$1882)$ & Eigenmann and Eigenmann, Diaphus suborbitalis Weber, \\
& Gonichthys cocco (Cocco), Lampadena cf. dea, Lampanyolodes \\
& hectoris (Günther), Myctophum affine (Lütken), \\
& Nannobrachium leucopsarum (Eigenmann \& Eigenmann), \\
& Nannobrachium ritteri (Gilbert), Parvilux ingens Hubbs and \\
& Wishner, Stenobrachius leucopsarus (Eigenmann \& \\
& Eigenmann), Symbolophorus californiensis (Eigenmann \& \\
& Eigenmann)
\end{tabular}

Cardiodectes cristatus Myctophidae Diaphanus suborbitalis (as D. glandulifer)

Shiino, 1958

Cardiodectes krishnai

Phosichthyidae

Vinciguerria luccetia (Garman)

Sebastian, 1968

Cardiodectes

Myctophidae

Myctophum apserum Richardson (as Dasiscopelus asper [sic])

longicervicus Shiino,

1958

Ophiolernaea longiceps

Sternoptychidae

Polyipnus spinifer Borodulina

[42]

Shiino, 1958

Parina myctophi

Myctophidae

Myctophum spinosum (Steindachner)

1977

composed of a mixture of shallow- and deep-water taxa $[4,23]$. Host-parasite relationships in deep-sea taxa in the family are shown in Table 2. Sarcotretes and Protosarcotretes seem to be limited to deep waters, while only a few members of Lernaeenicus and Cardiodectes infect deepsea fish. As already pointed out by Boxshall [5] and Boxshall \& Halsey [8], Sarcotretes scopeli and Cardiodectes bellottii (Richiardi, 1882) (as C. medusaeus (Wilson, 1908) exhibit low host-specificity, utilizing a wide range of fish families or genera. Sarcotretes scopeli infects eight families of fish, while $C$. bellottii parasitizes only Myctophidae. The Stomiidae host family utilized by $P$. nishikawai has only rarely been reported as a host of pennellids in contrast to the family Myctophidae. It is interesting to note that Stomiiformes is generally thought to be basal relative to the Myctophidae [45], mirroring the condition in their copepod parasites. Visual observations with a Remotely-Operated Vehicle (ROV) have clearly recorded ectoparasitism of siphonostomatoid copepods such as Lernaeopodidae and Sphyriidae on deep-sea demersal fish, but not yet for Pennellidae [37]. This may partly be due to the relatively small-size of their bodies and partly due to their low abundances in the deep-sea.

The life cycle of Protosarcotretes is unknown, but can be deduced on the basis of that of other pennellids, especially Lernaeenicus sprattae (Sowerby, 1806) $[1,7,10,16,20,24,36,39,40,41,44,49]$. Basal pennellid groups such as Peniculus, Sarcotretes, Lernaeenicus [4,23] and Protosarcotretes may be characterized by the possession of a single host $[7,20,23]$. However, the number of developmental stages depends on the taxon. In Peniculus, Lernaeenicus and Peroderma two patterns with or without naupliar stages are recognized. i.e., 2 nauplii, 1 copepodid, 4 chalimi, and adult (in L. sprattae), and 1 copepodid, 4 chalimi, and adult (in Peroderma cylindricum Heller, 1868, Peniculisa shiinoi Izawa, 1965, and Peniculus minuticaudae Shiino, 1958) [2,20,21]. In $P$. cylindricum and $P$. shiinoi, only hatching stages were observed [2,21], while in L. sprattae and P. minuticaudae all post-embryonic developmental stages were fully described [20,39]. In deep-sea pennellids, the hatching stage is an infective copepodid in C. bellottii (Richiardi, 1882) [36], but is unknown in Sarcotretes and Protosarcotretes. Clarification of the life cycle would be possible if embryos developed to before the hatching stage were to be found inside the egg strings.

Acknowledgements. We would like to express our sincere thanks to Dr. R. Böttger-Schnack for her translation of Heller's (1865) German reference into English, and to Dr. B. A. Venmathi Maran for providing us with references on the Pennellidae. Thanks are due to Prof. Jun Nishikawa and the captain, crew and scientific party of the T/V Hokuto cruise. The photograph of the fresh, non-preserved animals was kindly provided by Mitsuko Hidaka-Umetsu. We also thank Dr. H. Yamamoto of the Environmental Impact Assessment Research Group, within the Research and Development Center for Submarine Resources, JAMSTEC, for his support, and Dr. M. Shimomura for his dealing with the materials of the parasitic copepod and its host 
fish in Kitakyushu Museum of Natural History and Human History, Japan. This study is a contribution to the International Network for Scientific Investigations of Deep-Sea Ecosystems (INDEEP), and the Deep Ocean Stewardship Initiative (DOSI). This study was partially supported by grants-in-aid by KAKENHI from the Japan Society of the Promotion of Science (Nos 16K07825, 24248032，26304030，23405031), JST grant CREST, the fund for Interdisciplinary Collaborative Research by the Atmosphere and Ocean Research Institute, University of Tokyo, and the Cross-ministerial Strategic Innovation Promotion Program (SIP) for the Development of New-generation Research Protocols for Submarine Resources; Core Research for Evolutional Science and Technology. The authors declare that they have no conflicts of interest.

\section{References}

1. Anstensrud M, Schram TA. 1988. Host and site selection by larval stages and adults of the parasitic copepod Lernaeenicus sprattae (Sowerby)(Copepoda, Pennellidae) in the Oslofjord. Hydrobiologia, 167, 587-595.

2. Bennet PS. 1961. Peroderma cylindricum Heller, a copepod parasite of Sardinella albella. Journal of the Marine Biological Association of India, 3, 70-74.

3. Bharadhirajan P, Gopalakrishnan A, Raja K, Murugan S, Vijayakumar R, Rahman MM. 2013. Prevalence of copepod parasite (Lernaeenicus polynemi) infestation on Eleutheronema tetradactylum from Pazhayar coastal waters, southeast coast of India. Journal of Coastal Life Medicine, 1, 258-261.

4. Boxshall GA. 1986. A new genus and two new species of Pennellidae (Copepoda: Siphonostomatoida) and an analysis of evolution within the family. Systematic Parasitology, $8,215-225$.

5. Boxshall GA. 1998. Host specificity in copepod parasites of deep-sea fishes. Journal of Marine Systems, 15, 215-223.

6. Boxshall GA. 2000. Parasitic copepods (Copepoda: Siphonostomatoida) from deep-sea and mid-water fishes. Systematic Parasitology, 47, 173-181.

7. Boxshall GA. 2005. Copepoda (copepods), in Rohde K. (Ed.), Marine Parasitology. Collingwood: CSIRO Publishing, p. 123-138.

8. Boxshall GA, Halsey SH. 2004. An Introduction to Copepod Diversity. London: The Ray Society.

9. Boxshall GA, Walter TC. 2012. Pennellidae Burmeister, 1835. In: Walter TC, Boxshall GA. 2017. World of Copepods database. Accessed through: World Register of Marine Species at http://www.marinespecies.org/aphia. php? $\mathrm{p}=$ taxdetails\&id $=135532$ on $2017-12-06$

10. Brooker A, Bron J, Shinn A. 2012. Description of the freeswimming juvenile stages of Lernaeocera branchialis (Pennellidae), using traditional light and confocal microscopy methods. Aquatic Biology, 14, 153-163.

11. Castro Romero R. 2014. Two new genera of pennellids (Copepoda, Siphonostomatoida): Propeniculus and Pseudopeniculus, each with a new combination, Propeniculus trichiuri (Gnanamuthu, 1951) and Pseudopeniculus asinus (Kabata \& Wilkes, 1977). Crustaceana, 87, 551-569.

12. Castro Romero R, Kuroki HB. 1989. Characters of the Pennellidae based on Peniculus, Metapeniculus, Trifur, Lernaeenicus and Lernaeocera, specimens study with SEM. Estuda Oceanologia, 8, 21-44.

13. Cherel Y, Boxshall GA. 2004. Sarcotretes (Copepoda: Pennellidae) parasitizing myctophid fishes in the Southern Ocean: new information from seabird diet. Journal of Parasitology, 90, 1288-1292.
14. FishBase. 2017. Ver. (06/2017) at http://www.fishbase. org/search.php on 2017-10-17

15. Heller C. 1865. Reise der Österreucguscgeb Fregatte Novara um die Erde in den Jahren 1857, 1858, 1859. den Befehlen des Commodore B. von Wüllerstorf-Urbair. Zoologischer Theil, zveiter Band, dritte Abtheilung, Crustaceen, Viena, $4,1-280$.

16. Ho JS. 1966. Larval stages of Cardiodectes sp. (Caligoida: Lernaeoceriformes), a copepod parasitic on fishes. Bulletin of Marine Science, 16, 159-199.

17. Ho JS, Nagasawa K, Kim IH. 2007. Sarcotretes longirostris n. sp. (Copepoda: Pennellidae) parasitic on bluefin driftfish (Psenes pellucidus) from the stomachs of short-finned pilot whales caught off Japan. Journal of Crustacean Biology, 27, $116-120$.

18. Hogans WE. 1988. Review of Sarcotretes Jungersen, 1911 (Copepoda: Pennellidae) from midwater and demersal fishes in the north Atlantic Ocean. Canadian Journal of Zoology, $66,1371-1375$.

19. Huys R, Boxshall GA. 1991. Copepod Evolution. London: The Ray Society.

20. Ismail N, Ohtsuka S, Venmathi Maran BA, Tasumi S, Zaleha K, Yamashita H. 2013. Complete life cycle of a pennellid Peniculus minuticaudae Shiino, 1956 (Copepoda: Siphonostomatoida) infecting cultured threadsail filefish, Stephanolepis cirrhifer. Parasite, 20, 42.

21. Izawa K. 1997. The copepodid of Peniculisa shiinoi Izawa, 1965 (Copepoda, Siphonostomatoida, Pennellidae), a single free-swimming larval stage of the species. Crustaceana, 70, 911-919.

22. Jungersen HFE. 1911. On a new gymnoblastic hydroid (Ichthyocodium sarcotretis) epizoic on a new parasitic copepod (Sarcotretes scopeli) infesting Scopelus glacialis Rhdt. Videnskabelige Meddeleser fra Dansk Naturhistorisk Forening, 64, 1-33.

23. Kabata Z. 1979. Parasitic Copepoda of British fishes. London: The Ray Society.

24. Kearn GC. 2004. Leeches, lice and lamprey. A natural history of skin and gill parasites of fishes. Dordrecht: Springer.

25. Knoff M, Boeger WA. 1994. Expanded description of the female of Lernaeenicus longiventris Wilson, 1917 (Copepoda, Siphonostomatoida, Pennellidae) based on specimens from Mugil platanus Günter, 1880 (Perciformes, Mugilidae) of the state of Rio de Janeiro, Brazil. Memórias do Instituto Oswaldo Cruz, 89, 313-317.

26. Leigh-Sharpe WH. 1934. The Copepoda of the Siboga Expedition. Part II. Commensal and parasitic Copepoda. Siboga Expedition Monograph, 29b, 1-43.

27. Lewis AG. 1959. A new species of parasitic copepod of the family Lernaeidae, Lernaeenicus multilobatus, from a deepsea angler-fish. Bulletin of Marine Science, 9, 169-173.

28. Nagasawa K, Mukai T, Sota K, Yamauchi T. 2010. Heavy infection of groupers Epinephelus spp. with Lernaeenicus ramosus (Copepoda, Pennellidae) in the Sea of Japan. Biogeography, 12, 13-15.

29. Nakabo T. 2013. Fishes of Japan with pictorial keys to the species, 3rd edition. Hadano: Tokai University Press (In Japanese).

30. Oldewage WH. 1989. A new species of Lernaeenicus (Copepoda: Siphonostomatoida) from southern Africa. South African Journal of Zoology, 24, 319-321.

31. Pascual S, Gestal C, Estévez JM, Rodríguez H, Soto M, Abollo E, Arias C. 1996. Parasites in commerciallyexploited cephalopods (Mollusca, Cephalopoda) in Spain: an update perspective. Aquaculture, 142, 1-10.

32. Pascual, S., Gestal, C., Abollo, E. (1997). Effect of Pennella sp. (Copepoda, Pennellidae) on the condition of Illex 
coindetii and Todaropsis eblanae (Cephalopoda, Ommastrephidae). Bulletin-European Association of Fish Pathologists, 17, 91-95.

33. Pascual S, González A, Guerra A. 1998. Effect of parasitism on the productivity of the ommastrephid stocks in Galician waters (NW Spain): economic loss. Iberus, 16, 13-14.

34. Pascual S, González AF, Gestal C, Abollo E, Guerra A. 2001. Epidemiology of Pennella sp. (Crustacea: Copepoda), in exploited Illex coindetii stock in the NE Atlantic. Scientia Marina, 65, 307-312.

35. Pascual S, González AF, Guerra A. 2005. The recruitment of gill-infesting copepods as a categorical predictor of size-atage data in squid populations. ICES Journal of Marine Science, 62, 629-633.

36. Perkins PS. 1983. The life history of Cardiodectes medusaeus (Wilson), a copepod parasite of lanternfishes (Myctophidae). Journal of Crustacean Biology, 3, 70-87.

37. Quattrini AM, Demopoulos AW. 2016. Ectoparasitism on deep-sea fishes in the western North Atlantic: In situ observations from ROV surveys. International Journal for Parasitology: Parasites and Wildlife, 5, 217-228.

38. Raja K, Saravanakumar A, Gopalakrishnan A, Vijayakumar R, Hwang UW, Venmathi Maran BA. 2016. The genus Lernaeenicus Lesueur (Copepoda, Siphonostomatoida, Pennellidae) in India: a checklist with notes on its taxonomy and ecology. Zootaxa, 4174, 192-211.

39. Schram TA. 1979. The life history of the eye-maggot of the sprat, Lernaeenicus sprattae (Sowerby) (Copepoda, Lernaeoceridae). Sarsia, 64, 279-316.

40. Schram TA, Ansteinsrud, M. 1985. Lernaeenicus sprattae (Sowerby) larvae in the Oslofjord plankton and some laboratory experiments with the nauplius and copepodid (Copepoda, Penellidae). Sarsia, 70, 127-134.

41. Sebastian MJ, George KC. 1964. Lernaeenicus anchoviellae n. sp. (Copepoda-Lernaeidae) parasitic on Anchoviella bataviensis (Hardenberg) with descriptions of its three post-larval stages. Journal of the Marine Biological Association of India, 6, 235-240.
42. Shiino SM. 1958. Copepods parasitic on Japanese fishes. 17. Lernaeidae. Report of the Faculty of Fisheries, Prefectural University of Mie, 3, 75-100.

43. Shiino SM. 1965. Parasitic copepods of the eastern Pacific fishes. 7. Lernaeenicus hemiramphi Gnanamuthu. Report of the Faculty of Fisheries Prefectural University of Mie, 5, $435-440$

44. Sproston NG. 1942. The developmental stages of Lernaeocera branchialis (Linn.). Journal of the Marine Biological Association of the United Kingdom, $25,441-466$.

45. Stiassny MLJ, Wiley EO, Johnson GD, de Carvalho MR. 2004. Gnathostome fishes in Assembling the tree of life, Cracraft J, Donoghue MJ, Editors. Oxford University Press: Oxford. p. 410-429

46. Uyeno D, Wakabayashi K, Nagasawa K. 2012. A new species of parasitic copepod, Sarcotretes umitakae sp. n. (Siphonostomatoida, Pennellidae), on the rattail (Actinopterygii, Macrouridae) from the East China Sea, Japan. ZooKeys, 246, 1-10.

47. Venmathi Maran BA, Moon SY, Oh SY, Soh HY, Myoung JG. 2012. Redescription of two pennellids (Copepoda, Siphonostomatoida) from Korea with a key to species of Peniculus von Nordmann, 1832. ZooKeys, $243,1-14$.

48. Venmathi Maran BA, Oh SY, Choi HJ, Myoung JG. 2014. Seasonal occurrence and habitat of two pennellids (Copepoda, Siphonostomatoida) infecting marine ranched black scraper and Korean rockfish in Korea. Tropical Biomedicine, 31, 362-369.

49. Wilson CB. 1917. North American parasitic copepods belonging to the family Lernaeidae with a revision of the entire family. Proceeding of the United States National Museum, 53, 1-150.

50. Yamaguti S, Utinomi H. 1953. Lernaeenicus quadrilobatus n. sp. (Copepoda, Lernaeidae) parasitic on the lantern-fish Diaphus coeruleus. Publication the Seto Marine Biological Laboratory, 3, 51-53.

Cite this article as: Ohtsuka S, Lindsay DJ, Izawa K. 2018. A new genus and species of the family Pennellidae (Copepoda, Siphonostomatoida) infecting the Pacific viperfish Chauliodus macouni. Parasite 25, 6

\section{PARASTE}

Reviews, articles and short notes may be submitted. Fields include, but are not limited to: general, medical and veterinary parasitology; morphology, including ultrastructure; parasite systematics, including entomology, acarology, helminthology and protistology, and molecular analyses; molecular biology and biochemistry; immunology of parasitic diseases; host-parasite relationships; ecology and life history of parasites; epidemiology; therapeutics; new diagnostic tools.

All papers in Parasite are published in English. Manuscripts should have a broad interest and must not have been published or submitted elsewhere. No limit is imposed on the length of manuscripts.

Parasite (open-access) continues Parasite (print and online editions, 1994-2012) and Annales de Parasitologie Humaine et Comparée (1923-1993) and is the official journal of the Société Française de Parasitologie. 